\title{
Extensive Multifocal Mammary Infarction - a Case Report
}

\author{
Allison A. Aggon Lori Oetting Eakin Nicole DeSimone Justin A. Snyder \\ Pinnacle Health Community Campus, Harrisburg, PA, USA
}

\section{Keywords}

Differential diagnosis - Pregnancy - Radioimaging •

Review · Screening · Ultrasound · Mammary infarction

\section{Summary}

Background: Breast infarction can occur in benign breast lesions, such as fibroadenomas, as well as healthy breast tissue, typically in the gravid or lactating patient. Few theories, however, exist to explain this unusual lesion. Case Report: We present a very rare case of a 27-year-old female patient with extensive, multifocal, bilateral mammary infarction. A literature search was also performed to confirm its rarity. Although solitary or limited areas of spontaneous infarction have been documented, there are no documented cases where such a large, multifocal area of involvement has occurred without obvious explanation. Conclusion: Extensive multifocal post-partum breast infarction is a rare occurrence that has potential long-term effects. This should be considered when taking patient history in post-partum patients, as well as those with extensive calcifications on mammogram years after giving birth.

\section{Introduction}

Discovery of a new breast mass in the gravid patient poses a significant diagnostic challenge for physicians and worry for patients. Regardless of symptoms, a new mass requires a thorough evaluation that includes pathologic diagnosis to rule out a malignancy in this difficult to treat population [1]. The most common etiologies for breast masses in the gravid patient include fibroadenoma, mastitis, abscess, galactoceles, and very rarely, breast infarction [1]. Although only occasionally seen, the concept of localized mammary infarction during

\author{
Schlüsselwörter \\ Differentialdiagnose - Schwangerschaft - Radiographie · \\ Übersicht · Screening · Ultraschall · Mammainfarkt
}

\section{Zusammenfassung}

Hintergrund: Mammainfarkte können sowohl im Zusammenhang mit gutartigen Mammaläsionen (z.B. Fibroadenomen) als auch im gesunden Brustgewebe auftreten und betreffen typischerweise schwangere bzw. laktierende Patientinnen. Es gibt nur wenige Theorien bezüglich der Ursache dieser ungewöhnlichen Erkrankung. Fallbericht: Wir berichten über den äußerst seltenen Fall einer 27-jährigen Patientin mit ausgedehntem, multifokalen, bilateralen Mammainfarkt. Außerdem wurde eine Literatursuche durchgeführt, um die Seltenheit eines solchen Infarkts zu bestätigen. Zwar wird von einzelnen oder begrenzten spontanen Infarkten berichtet, jedoch gibt es keine dokumentierten Fälle eines umfangreichen, multifokalen Infarkts ohne ersichtliche Ursache. Schlussfolgerung: Ein ausgedehnter, multifokaler, postpartaler Mammainfarkt ist ein seltenes Ereignis mit potentiellen Langzeitfolgen. Er sollte als mögliche Differentialdiagnose bei postpartalen Patientinnen sowie Patientinnen mit großflächigen Kalzifikationen im Mammogramm Jahre nach der Entbindung in Betracht gezogen werden.

or shortly after pregnancy has been documented as early as the 1960s. Symptoms can range anywhere from being virtually absent to pain and bloody discharge secondary to tissue necrosis [2]. The specific cause of mammary infarction has yet to be definitively established, however, theories include vascular insufficiency and localized thrombosis [3]. Accurate diagnosis is critical since breast infarction can histologically appear similar to carcinoma, thus potentially leading to an incorrect diagnosis and treatment by the physician [4]. We present a rare case of a 27-year-old female with extensive, multifocal, bilateral mammary infarction. The

\section{KARGER}

Fax +497614520714

Information@Karger.com

www.karger.com

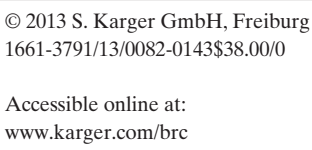

Dr. Allison A. Aggon 
diagnosis, potential etiology, treatment, as well as follow-up recommendations will be discussed.

\section{Case Report}

A 27-year-old woman presented 2 weeks post-partum to her primary care physician (PCP) complaining of a firm, 2-cm right breast lump unchanged in size since she first noticed it 2 days after giving birth to her first child. The patient denied pain, swelling, nipple discharge, fevers, or similar episodes in the past. The mass was tender to the touch, freely mobile without underlying skin retraction or dimpling, and no lymphadenopathy was appreciated. Her past medical history was significant for menarche at age 13, hypothyroidism, anxiety, depression, and chronic back pain. Her surgical history was significant for tonsil and sinus surgery, partial thyroidectomy, left-sided ductal excision for a benign discharge as a teenager, and a right-sided breast biopsy for a fibroadenoma. She denied any history of trauma or breast cancer. Her family history was significant for multiple great aunts having post-menopausal breast cancer. She admitted to minimal caffeine use and social alcohol use.

Shortly after childbirth, she was started on paroxetine for post-partum depression, so she did not breastfeed. Her PCP diagnosed her mass as mastitis and started her on a 1-week course of cefalexin. At her follow-up appointment, the initial right breast lump appeared smaller, however, numerous smaller lumps subsequently developed in both breasts. These were firm, non-tender, and presented in the upper and medial breast quadrants, more pronounced in the right than in the left breast. An ultrasound of both breasts revealed too-numerous-to-count solid and complex-cystic masses bilaterally, the largest measuring $1.9 \times 1.2 \times 2.2 \mathrm{~cm}$ (fig. 1). Ultrasound-guided vacuum-assisted core biopsies were obtained from the 2 most prominent and symptomatic masses which happened to be in the right breast. Pathology results showed large zones of infarcted breast tissue with adjacent fibrosis, foamy histiocytes, and residual epithelium, as well as lactation hyperplasia (fig. 2). There was no evidence of malignancy. Bilateral mammograms were then performed and showed numerous non-specific densities with benign scattered calcifications most prominent in the medial regions (figs. $3 \mathrm{a}$ and $\mathrm{b}$ ) It was decided to not biopsy areas of the left breast because none of the masses in the left breast were symptomatic at that time and were radiographically identical to the right side.

The patient continued to lactate for 10 months post-partum despite not breastfeeding. She did not experience any pain, swelling, infection, or new lumps during her follow-up appointments. The initial lumps were noted to have resolved on physical exam. Unfortunately, the patient refused further reevaluation with imaging.

\section{Discussion}

Although solitary spontaneous infarction has been well documented, it is exceptionally rare to have such a large, multifocal area of involvement. Most reports are from over 20 years ago, with only 28 cases documented as of 1986 [3, 5, 6, 8]. The extent of infarction is usually described as a single lesion, localized to a fibroadenoma or hyperplastic lactating breast tissue in a peri-partum patient. About $0.5-1.5 \%$ of fibroadenomas infarct, and are associated with pregnancy or lactation [2,7]. Of the limited number of cases that have been documented, no long-term follow-up has been reported. Only 1 documented case of extensive bilateral mammary infarction has been identified. In a 1964 case report, Wilkinson and Green [8] described a woman with markedly nodular breasts and extensive bilateral infarction. She had massive bilateral breast hypertrophy with multiple surgical reductions that may have contributed to her unusually large area of involvement.

Pathologic findings of mammary infarction tend to be consistent with having a yellow-gray gross appearance and microscopic evidence of hemorrhage and breast tissue fibrosis or hyperplasia [6,9]. There have been reports of difficulty in distinguishing fine needle aspiration samples of infarcted, benign breast tissue and malignant tissue [4]. Pathologists and surgeons have used WCAFTI (Worrisome Cytological Alterations Following Tissue Infarction) to describe the range of cytological findings associated with epithelial infarction, including poorly preserved pleomorphic single cells with variable morphology and vesicular to pyknotic nuclei with anisonucleosis [4]. Because of this, it would be beneficial to have a low threshold for a core needle biopsy instead for women with concerning post-partum masses.

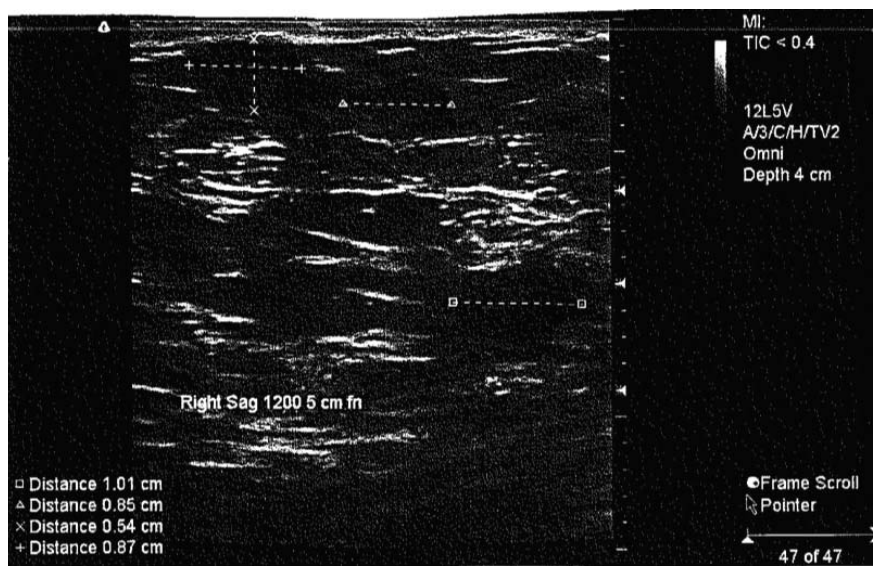

Fig. 1. Ultrasound of the right breast with multiple masses.

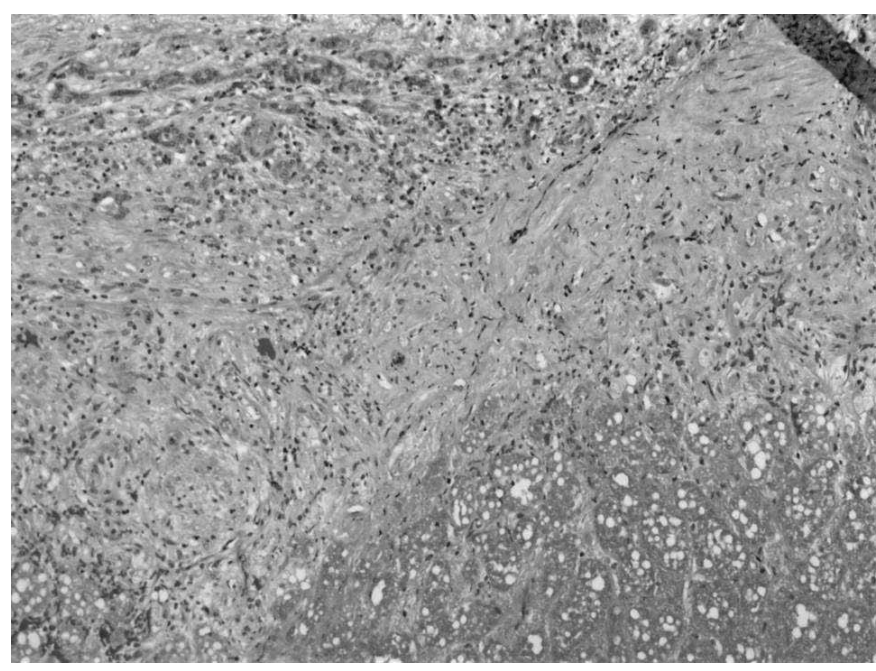

Fig. 2. Histological slide of right breast biopsy showing breast necrosis. 

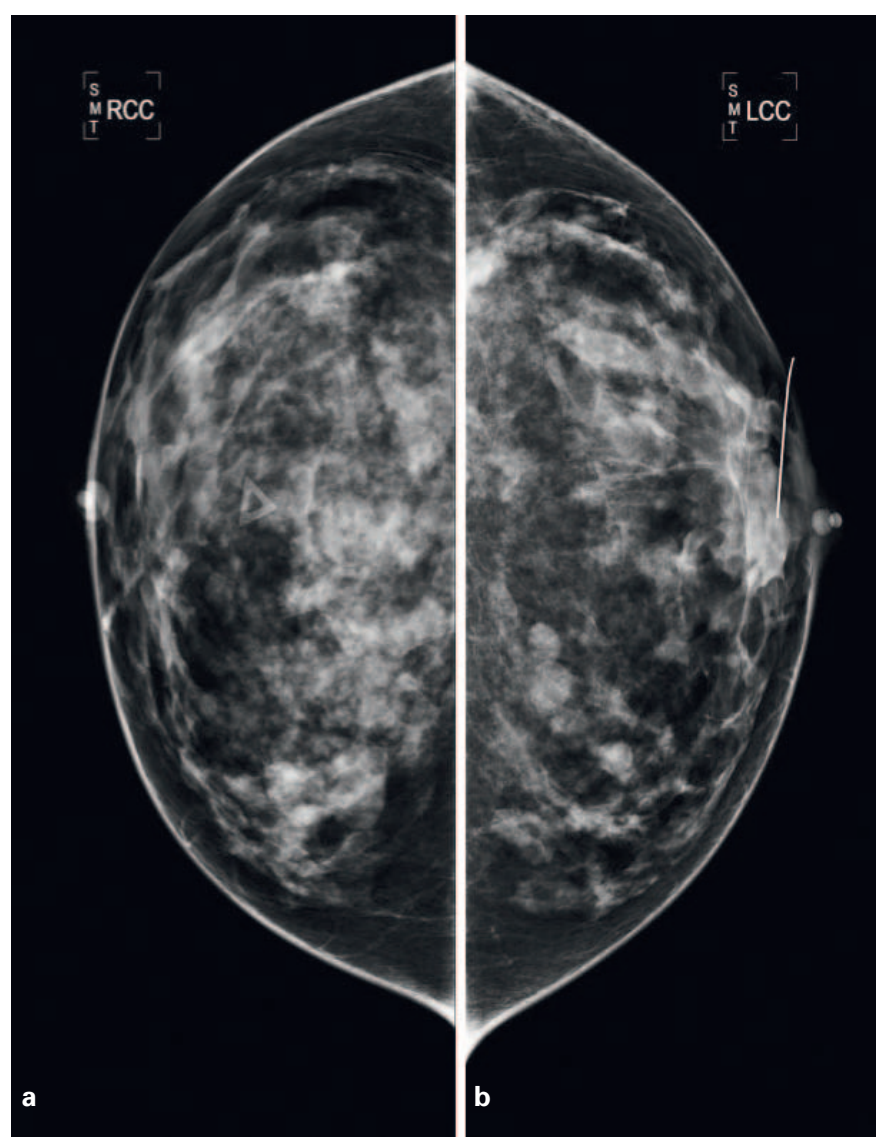

Fig. 3. a Mammogram of right breast, $\mathrm{CC}$ view. b Mammogram of the left breast, $\mathrm{CC}$ view.

A number of complex-cystic structures were seen alongside areas of necrosis on ultrasound, which may represent underlying fibrocystic disease or dilated ducts. These were not pathologically confirmed. One could argue that certain medications may exacerbate fibrocystic disease or breast vascularity resulting in increased mass formation and necrosis, how- ever, none of the patient's medications have been known to cause breast complications.

Annual mammograms after infarction could possibly show us if multifocal infarction creates extensive calcification. These calcifications could make for more difficult cancer detection on mammograms in the future, or even cause unnecessary breast biopsies to be performed. Breast exams at these times will also be of interest to see if complete spontaneous resolution eventually occurs, especially once lactation has ceased. Follow-up ultrasounds could also be helpful to monitor changes. The use of magnetic resonance imaging could potentially be beneficial with mass evaluation, although it would not be ideal for calcification monitoring.

\section{Conclusion}

Extensive multifocal post-partum breast infarction is a rare occurrence that has potential long-term effects. This should be considered when taking patient history in post-partum patients, as well as those with extensive calcifications on mammogram years after giving birth. Although solitary or limited areas of spontaneous infarction have been documented, it is very rare to have such a large, multifocal area of involvement. To our knowledge there have been no documented cases of multifocal involvement to date, and long-term effects and follow-up guidelines have not been established. Whether future lactation is compromised and if complete spontaneous resolution occurs has not been reported making further research regarding this topic critical to advancement in diagnosis and treatment of breast infarction.

\section{Disclosure Statement}

There are no potential conflicts of interest, sources of financial support, corporate involvement, etc. for any of the authors.

\section{References}

1 Woo CJ, Yu T, Hurd T: Breast cancer in pregnancy. Arch Surg 2003;138:91-98.

2 Fowler C: Spontaneous infarction of fibroadenoma in an adolescent girl. Pediatr Radiol 2004;34:988990.

3 Lucey J: Spontaneous infarction of the breast. J Clin Path 1975;28:937-943.
4 Kavdia R, Kini U: WCAFTI-worrisome cytologic alterations following tissue infarction; a mimicker of malignancy in breast cytology. Diagn Cytopathol 2008:36:586-588.

5 Jimenez J, Ryals R, Cohen C: Spontaneous breast infarction associated with pregnancy presenting as a palpable mass. J Surg Oncol 1986;32:174-178.

6 Pambakian H, Tighe J: Mammary infarction. Br J Surg 1971;58:601-602.
7 Matias-Guiu X, Calabuig R, Badia F, Serra J, La Calle JP: Spontaneous infarcts in fibroadenomas of the breast. Curr Surg 1988;45:277-279.

8 Wilkinson L, Green W: Infarction of breast lesions during pregnancy and lactation. Cancer 1964;17:1567-1572.

9 Rickert R, Rajan S: Localized breast infarcts associated with pregnancy. Arch Pathol 1974;97:159-161. 